\title{
UJI TOKSISITAS EKSTRAK RIMPANG TEMU HITAM (Curcuma aeruginosa Roxb.) TERHADAP LARVA UDANG (Artemia salina Leach) DENGAN METODE BRINE SHRIMP LETHALITY TEST (BSLT)
}

\author{
*)Zulfiah, *)Megawati, *) Herman, *)Sulfiyana H. Ambo Lau, *)Muh. Farid Hasyim, *)Murniati, \\ *)Alfreds Roosevelt, *)Yuniharce Kadang, *)Nurul Izza, *)Gerfan Patandung \\ *)Akademi Farmasi Sandi Karsa Makassar \\ *)Program Studi D-III Farmasi Sandi Karsa Makassar
}

\begin{abstract}
ABSTRAK
Penelitian ini bertujuan mengetahui adanya potensi toksisitas dari ekstrak rimpang temu hitam terhadap larva udang Artemia salina Leach dengan metode BSLT. Desain penelitian yang digunakan adalah eksperimental laboratorium yang dilaksanakan di Laboratorium Biologi Sekolah Tinggi Ilmu Farmasi Makassar. Tumbuhan rimpang temu hitam (Curcuma aeruginosa Roxb.) merupakan salah satu tumbuhan yang berada di Indonesia dan memiliki banyak khasiat. Tanaman ini mengandung senyawa alkaloid, saponin, flavonoid dan kurkuminoid. Penelitian ini mengunakan sampel ekstrak etanol, hewan uji yang digunakan berupa Artemia salina Leach yang dibagi dalam 5 kelompok tiap kelompok terdiri dari 10 ekor larva yang dimasukkan kedalam vial. Konsentrasi yang digunakan adalah $20 \mathrm{ppm}, 40 \mathrm{ppm}, 60 \mathrm{ppm}, 80 \mathrm{ppm}$ dan $100 \mathrm{ppm}$ dan terdapat juga kontrol negatif. Pengamatan terhadap larva yang mati dilakukan 24 jam setelah pemberian sampel uji. Data persen kematian larva Artemia salina Leach dibuat persamaan regresi linier dengan membuat persamaan garis lurus yang menghubungkan antara nilai log konsentrasi dan nilai probit. Hasil penelitian bahwa ekstrak etanol rimpang temu hitam memiliki nilai $\mathrm{LC}_{50} 37,73115$ ppm. Pemberian kelima konsentrasi yang berbeda pada penelitian ini menunjukkan potensi toksisitas terhadap larva Artemia salina Leach.
\end{abstract}

Kata kunci: Rimpang Temu Hitam, BSLT, dan Artemia salina Leach.

\section{PENDAHULUAN}

\section{A. Latar Belakang}

Penggunaan suatu jenis tanaman sebagai obat herbal merupakan suatu alternatif yang dilakukan oleh masyarakat untuk mendapatkan pengobatan. Tanaman herbal yang diduga memiliki potensi untuk menyembuhkan berbagai macam penyakit terlabih dahulu harus melewati beberapa tahap sebelum akhirnya dapat dijadikan suatu sediaan obat. Sesuai dengan PermenkesNo.760/Menkes/Per/IX/1992, yang membahas tentang obat tradisional dan fitofarmaka, maka setiap bahan alam yang akan digunakan sebagai sumber obat, harus melewati beberapa pengujian sehingga dapat memenuhi syarat yang telah ditentukan dana man dikonsumsi oleh masyarakat luas (Permenkes, 1992). Secara umum, kegunaan tumbuhan obat sebenarnya disebabkan oleh kandungan kimia yang dimiliki. Namun, tidak seluruh kandungan kimia diketahui secara lengkap karena pemeriksaan bahan kimia dari suatu tanaman memerlukan biaya yang mahal. Meskipun secara rinci, tetapi pendekatan farmakologi menghasilkan informasi kegunaan tumbuhan obat (Hariana, 2006).

Manusia telah beradaptasi selama jutaan tahun dengan senyawa-senyawa tanaman obat.
Hal ini membuat tubuh manusia mampu secara alami mengambil manfaat dari komponen tanaman obat dan menyaring racun-racun berbahaya di dalamnya. Sebaliknya tubuh manusia umumnya masih kesulitan menyesuaikan diri dalam mengkonsumsi obatobatan yang menjadi andalan dunia pengobatan barat. Reaksi kimia obat-obatan modern biasa jauh lebih merugikan misalnya menimbulkan cacat atau mematikan dibandingkan dengan obat-obatan herbal (Astrid, 2016).

Salah satu tanaman yang potensial sebagai obat herbal adalah temu hitam (Curcuma aeruginosa Roxb.). Tanaman ini banyak tumbuh di wilayah tropis seperti di Indonesia yang sering dijumpai di beberapa daerah salah satunya di kabupaten.

Curcuma aeruginosa Roxb. atau temu hitam memiliki nama lokal temu ireng diduga memiliki aktivitas sitotoksik karena mengandung minyak atsiri, kurkuminoid, alkaloid, lemak, tanin, amilum, saponin, polifenol dan senyawa bioaktif yaitu flavonoid dan kurkuminoid yang dikenal memiliki aktivitas antikanker. Rimpang temu hitam secara empiris memiliki khasiat untuk menambah nafsu makan, meredakan nyeri, menghilangkan bengkak, membersihkan darah paska melahirkan, menyuburkan kandungan, 
mengatasi nyeri saat menstruasi, batuk berdahak, menyembuhkan sesak nafas, mengatasi penyakit kulit, mengatasi perut mulas, menyembuhkan luka, sariawan dan mengatasi penyakit cacingan (Suparni, 2012). Potensi tanaman temu hitam sebagai salah satu obat alternatif telah banyak dikembangkan dan dilakukan berbagai peneliti seperti yang dilakukan oleh Fitri tahun 2015 mengenai senyawa flavonoid, alkaloid dan saponin dalam rimpang temu hitam memiliki potensi antiproliferasi atau penghambatan pada sel lestari tumor dan memiliki fungsi sebagai apoptosis selular yang semakin meningkat seiring dengan peningkatan konsentrasi ekstrak yang diberikan. Kemudian pada tahun 2016 Rizky melakukan penelitian pada potensi senyawa flavonoid dalam rimpang temu hitam dapat berfungsi sebagai imunomodulator yang dapat meningkatkan mekanisme pertahan tubuh serta penelitian Khodijah tahun 2018 bahwa kandungan minyak atsiri dalam rimpang temu hitam sebagai antibakteri yang kuat serta beberapa penelitian lainnya mengenai berbagai aktivitas temu hitam untuk pengobatan. Namun penelitian mengenai toksisitas dari rimpang temu hitam masih sangat terbatas.

Sebagai skrining awal untuk mendeteksi kemampuan ekstrak rimpang temu hitam maka dilakukan uji toksisitas. Toksisitas dari suatu senyawa secara umum dapat diartikan sebagai potensi dari suatu senyawa kimia untuk dapat menyebabkan kerusakan ketika senyawa tersebut mengenai atau masuk kedalam tubuh manusia. Pada penelitian ini dilakukan uji toksisitas akut, yakni salah satu jenis pengujian toksisitas yang digunakan untuk menentukan dosis $\mathrm{LC}_{50}$ atau $\mathrm{LD}_{50}$ suatu senyawa setelah pemberian tunggal atau berulang dalam waktu 24 jam.

Uji toksisitas sebagai skrining awal dapat dilakukan dengan berbagai metode, salah satunya adalah dengan metode Brine Shrimp Lethality Test (BSLT). Metode Brine Shrimp Lethality Test merupakan suatu metode sebagai skrining awal untuk mendeteksi keberadaan senyawa toksik dalam proses isolasi senyawa bahan alam dengan menentukan nilai $\mathrm{LC}_{50}$ dari senyawa aktif. Metode ini telah terbukti memiliki hasil yang berkorelasi dengan kemampuan sitotoksik senyawa anti kanker (Mayer et al, 1982). Metode BSLT lazim digunakan untuk menentukan toksisitas suatu senyawa alam karena cepat, murah dan cukup akurat untuk skrining awal ekstrak aktif dengan menggunakan hewan uji larva udang sebagai bioindikator. Jenis udang Artemia salina Leach atau dengan nama lain udang Brine merupakan jenis udang primitif yang termasuk dalam family Artemiidae yang berumur 48 jam (Alam, 2003). Bila bahan yang diuji memberikan efek toksik terhadap larva udang dan menunjukkan nilai LC $_{50}$ (letal concentration) dibawah 1000 ppm berarti bahan tersebut memiliki potensi sebagai senyawa toksisitas. Hasil $\mathrm{LC}_{50}$ yang didapat dimasukkan kedalam kategorinya, $\mathrm{LC}_{50}$ yang lebih dari 1000 ppm termasuk. kategori tidak toksik, LC $_{50}$ 250-1000 ppm termasuk kategori lemah, $\mathrm{LC}_{50}$ 100-250 ppm termasuk dalam kategori yang sedang dari 30-100 ppm termasuk dalam kategori toksik kuat dan kurang dari 30 ppm merupakan kategori sangat toksik (Priyanto, 2009).

Berdasarkan uraian di atas, untuk mengoptimalkan pemanfaatan rimpang temu hitam sebagai sumber bahan obat maka peneliti tertarik melalukan uji toksisitas dari ekstrak temu hitam menggunakan Metode Brine Shrimp Lethality Test terhadap Artemia salina Leach.

\section{B. Rumusan Masalah}

Berdasarkan latar belakang di atas, maka rumusan masalah dari penelitian ini adalah apakah ekstrak rimpang temu hitam (Curcuma aeruginosa Roxb.) memiliki potensi toksisitas terhadap Artemia salina Leach dengan menggunakan metode Brine Shrimp Lethality Test (BSLT)?

\section{Tujuan Penelitian}

Tujuan dilakukan penelitian ini adalah untuk mengetahui potensi toksisitas ekstrak rimpang temu hitam (Curcuma aeruginosa Roxb.) terhadap Artemia salina Leach dengan menggunakan metode Brine Shrimp Lethality Test (BSLT).

\section{Manfaat Penelitian}

Manfaat dari penelitian ini adalah untuk memberikan data ilmiah, pengetahuan dan gambaran kepada penulis dan masyarakat mengenai potensi toksisitas dari rimpang temu hitam (Curcuma aeruginosa Roxb.) serta penggunaannya sebagai obat tradisional.

\section{METODE PENLITIAN}

\section{A. Jenis Penelitian}

Jenis penelitian ini yaitu penelitian eksperimen untuk mengetahui Uji Toksisitas Ekstrak Rimpang Temu Hitam (Curcuma aeruginosa Roxb.) Terhadap Larva Udang (Artemia salina Leach) Dengan Metode Brine Shrimp Lethality Test (BSLT).

\section{B. Tempat dan Waktu Penelitian}

Penelitian ini telah dilakukan di Laboratorium Mikrobiologi Akademi Farmasi 
Sandi Karsa Makassar pada bulan Maret 2020.

\section{Alat dan bahan}

Alat yang digunakan dalam penelitian ini antara lain, alat-alat gelas kimia $\left(\operatorname{Pyrex}^{\circledR}\right)$, gelas ukur $\left(\right.$ Pyrex $\left.^{\circledR}\right)$, vial, sendok tanduk, aluminium foil, batang pengaduk, kertas saring, pipet tetes, pipet mikro, timbangan analitik, lampu, kain flannel, seperangkat alat maserasi, rotary evaporator.

Bahan yang digunakan dalam penelitian ini antara lain, rimpang temu hitam (Curcuma aeruginosa Roxb.), aquadest, garam tidak beriodium, etanol 96\%, telur Artemia salina Leach, dimetilsulfoksida (DMSO $2 \%$ ) dan ragi.

\section{Metode Penelitian}

a. Proses Pengolahan Bahan Uji

1. Pengolahan awal

Temu hitam yang telah dipanen disortir dan dipisahkan antara batang dengan rimpang, kemudian dicuci dengan air mengalir hingga bersih, dilakukan perajangan untuk memperkecil ukuran dari rimpang dan dikeringkan dengan tidak terkena cahaya matahari langsung kemudian di potong kecil-kecil menjadi serbuk, hasil yang diperoleh digunakan sebagai bahan uji penelitian.

2. Pembuatan Ekstrak

Serbuk rimpang temu hitam ditimbang sebanyak 500 gram dan dimasukkan ke dalam bejana maserasi kemudian dilembabkan dengan cairan penyari etanol $96 \%$ dan didiamkan selama 15 - 30 menit. Selanjutnya dicukupkan dengan sisa etanol hingga seluruh sampel terendam sempurna. Kemudian didiamkan ditempat yang terlindung dari cahaya matahari selama 5 x 24 jam sambil sesekali di aduk lalu di saring. Residu di maserasi kembali (remaserasi) dengan cairan penyari yang sama seperti sebelumnya hingga tersari atau terekstraksi sempurna yang ditandai dengan warna cairan penyari menjadi bening kembali. Filtrat dikumpulkan dan diuapkan menggunakan vacum rotary evaporator kemudian diperoleh ektrak etanol kental

b. Pengujian Bebas Etanol

Identifikasi dilakukan dengan cara ekstrak dilarutkan dengan $\mathrm{H}_{2} \mathrm{SO}_{4}$ dalam tabung reaksi kemudian ditambahkan asam asetat dan ditutup dengan kapas, selanjutnya dipanaskan sampai mendidih setelah itu diidentifikasi bau ester pada kapas, jika ekstrak tidak mengandung etanol maka tidak tercium bau ester khas dari etanol.

c. Penetasan Artemia salina Leach

Telur udang ditetaskan 2 hari sebelum dilakukan pengujian. Penetasan larva Artemia salina Leach dilakukan selama 48 jam. Penetasan dilakukan dengan cara merendam telur tersebut dalam air laut buatan (50 gram garam tidak beriodium atau garam ikan dalam $800 \mathrm{ml}$ aquadest dengan ph 7-9 seperti air laut murni) pada wadah botol plastik ukuran $1 \mathrm{~L}$ yang telah di potong sisi bagian bawahnya sehingga berbentuk kerucut sebagai pengganti akuarium. Sebelumnya wadah botol plastik dipasang aerator, aerator ini berguna untuk menjaga kadar oksigen dalam wadah. Wadah botol plastik yang telah terisi telur dan telah dipasangi aerator selanjutnya diletakkan diruang yang cukup cahaya atau diberi penerangan dengan cahaya lampu neon 5 watt untuk menghangatkan suhu penetasan agar suhu penetasan $25-30^{\circ} \mathrm{C}$ tetap terjaga dan merangsang proses penetasan.. Cahaya ini berfungsi untuk pertumbuhan larva Artemia salina Leach. Dalam waktu $2 \times 24$ jam telur akan berubah menjadi larva Artemia salina Leach dan akan digunakan sebagai hewan uji untuk pengujian toksisitas (Reskianingsih, 2015).

d. Pembuatan Larutan Stok

Ekstrak kental rimpang temu hitam yang akan diuji, ditimbang sebanyak $100 \mathrm{mg}$ kemudian dilarutkan dengan DMSO 2\% 1-3 tetes untuk melarutkan ekstrak lalu ditambahkan hingga $100 \mathrm{~mL}$ air laut buatan sehingga diperoleh konsentrasi 1000 ppm yang akan digunakan sebagai larutan induk. Masing-masing ekstrak kemudian diencerkan sehingga diperoleh konsentrasi 20, 40, 60, 80, dan 100 ppm.

e. Pembuatan Larutan Uji

Rumus pengenceran :

$\mathrm{V}_{1} \times \mathrm{N}_{1}=\mathrm{V}_{2} \times \mathrm{N}_{2}$

Keterangan :

$\mathrm{V} 1=$ Volume awal

N1= Konsentrasi awal

$\mathrm{V} 2=$ Volume akhir

N2= Konsentrasi akhir

f. Pelaksanaan Uji Toksisitas

Sepuluh ekor larva dimasukkan kedalam tiap-tiap vial uji yang telah diberi sedikit air laut buatan dan ditambahkan satu tetes larutan ragi ( $3 \mathrm{mg}$ dalam $5 \mathrm{ml}$ air laut) sebagai nutrisi larva, kemudian volume air laut dicukupkan sampai $10 \mathrm{~mL}$, sedangkan larutan control hanya berisi air laut, satu tetes larutan ragi dan larva udang. Vial-vial uji kemudian didiamkan pada suhu kamar 
selama 24 jam. Setiap perlakuan diulang sebanyak tiga kali (triplo). Jumlah larva yang hidup dihitung dan ditentukan persentase kematian larva untuk mengetahui nilai $\mathrm{LC}_{50}$. Ekstrak yang mempunyai nilai $\mathrm{LC}_{50}<1000$ ppm dikatakan toksik (Meyer et al., 1982).Persentasi kematian larva dapat dihitung dengan rumus sebagai berikut: $\%$ Mortalitas $=\frac{\text { jumlah larva mati }}{\text { jumlah larva awal }} \times 100 \%$

g. Data yang diperoleh selanjutnya akan dianalisis dengan analisis probit untuk menentukan nilai $\mathrm{LC}_{50}$.

\section{HASIL DAN PEMBAHASAN}

\section{A. Hasil Penelitian}

Tabel I. Tabel 1. Hasil Ekstraksi

\begin{tabular}{cccc}
\hline Sampel & $\begin{array}{c}\text { Bobot } \\
\text { Simplisia (g) }\end{array}$ & $\begin{array}{c}\text { Bobot } \\
\text { Ekstrak (g) }\end{array}$ & $\begin{array}{c}\text { Rendemen } \\
(\%)\end{array}$ \\
\hline $\begin{array}{c}\text { Ekstrak } \\
\text { Etanol }\end{array}$ & 500 & 45 & 9 \\
\hline
\end{tabular}

Perhitungan rendemen : $\frac{\text { Bobot simplisia (akhir) }}{\text { Bobot simplisia baku (awal) }} \times 100 \%$

Tabel II. Hasil Pengamatan Persen (\%) Kematian Larva Udang (Arthemia salina Leach) Setelah Diberikan Ekstrak Rimpang Temu Hitam (Curcuma aeruginosa Robx.) Berdasarkan Metode ReedMuench.

\begin{tabular}{|c|c|c|c|c|c|c|c|c|c|c|c|c|c|c|c|c|}
\hline \multirow[t]{2}{*}{ Ko } & \multicolumn{6}{|c|}{ JLU } & \multicolumn{8}{|c|}{$\mathbf{K u}$} & \multirow{3}{*}{$\begin{array}{c}\mathbf{T} \\
\mathbf{K u}\end{array}$} & \multirow[t]{3}{*}{$\% \mathbf{K}$} \\
\hline & \multicolumn{3}{|c|}{$\mathbf{M}$} & \multicolumn{3}{|c|}{$\mathbf{H}$} & \multicolumn{3}{|c|}{$\mathbf{M}$} & \multirow{2}{*}{$\begin{array}{l}\mathbf{T} \\
\mathbf{M}\end{array}$} & \multicolumn{3}{|c|}{ H } & \multirow[t]{2}{*}{ TH } & & \\
\hline $\begin{array}{c}\text { Repli } \\
\text { kasi }\end{array}$ & 1 & 2 & 3 & 1 & 2 & 3 & 1 & 2 & 3 & & 1 & 2 & 3 & & & \\
\hline $\begin{array}{c}\text { Kon } \\
\text { trol } \\
(-)\end{array}$ & 0 & 0 & 0 & $\begin{array}{l}1 \\
0\end{array}$ & $\begin{array}{l}1 \\
0\end{array}$ & $\begin{array}{l}1 \\
0\end{array}$ & 0 & 0 & 0 & 0 & $\begin{array}{l}2 \\
7\end{array}$ & $\begin{array}{l}2 \\
8\end{array}$ & $\begin{array}{l}2 \\
7\end{array}$ & 82 & 82 & 0 \\
\hline $\begin{array}{c}20 \\
\mathrm{ppm}\end{array}$ & 4 & 4 & 3 & 6 & $\overline{6}$ & 7 & 4 & 4 & 3 & 11 & $\begin{array}{l}1 \\
7 \\
\end{array}$ & $\begin{array}{l}1 \\
8 \\
\end{array}$ & $\begin{array}{l}1 \\
7 \\
\end{array}$ & 52 & 63 & $\begin{array}{l}17, \\
46\end{array}$ \\
\hline $\begin{array}{c}40 \\
\mathrm{ppm}\end{array}$ & 5 & 5 & 6 & 5 & 5 & 4 & 9 & 9 & 9 & 27 & $\begin{array}{l}1 \\
1 \\
\end{array}$ & $\begin{array}{l}1 \\
2 \\
\end{array}$ & $\begin{array}{l}1 \\
0\end{array}$ & 33 & 60 & 45 \\
\hline $\begin{array}{c}60 \\
\mathrm{ppm}\end{array}$ & 6 & 5 & 7 & 4 & 5 & 3 & $\begin{array}{l}1 \\
5\end{array}$ & $\begin{array}{l}1 \\
4\end{array}$ & $\begin{array}{l}1 \\
6\end{array}$ & 45 & 6 & 7 & 6 & 19 & 64 & $\begin{array}{l}70, \\
31\end{array}$ \\
\hline $\begin{array}{c}80 \\
\mathrm{ppm}\end{array}$ & 9 & 8 & 7 & 1 & $\overline{2}$ & 3 & $\begin{array}{l}2 \\
4 \\
\end{array}$ & $\begin{array}{l}2 \\
2 \\
\end{array}$ & $\begin{array}{l}2 \\
3 \\
\end{array}$ & 69 & 2 & 2 & 3 & 7 & 76 & $\begin{array}{l}90, \\
78 \\
\end{array}$ \\
\hline $\begin{array}{l}100 \\
\mathrm{ppm}\end{array}$ & 9 & $\begin{array}{l}1 \\
0\end{array}$ & $\begin{array}{l}1 \\
0\end{array}$ & 1 & 0 & 0 & $\begin{array}{l}3 \\
3\end{array}$ & $\begin{array}{l}3 \\
2\end{array}$ & $\begin{array}{l}3 \\
3\end{array}$ & 97 & 1 & 0 & 0 & 1 & 98 & $\begin{array}{l}98, \\
97\end{array}$ \\
\hline
\end{tabular}

\section{Keterangan :}

$$
\begin{array}{ll}
\text { Ko } & \text { : konsentrasi } \\
\text { M } & : \text { mati } \\
\text { H } & : \text { hidup } \\
\text { HLU } & : \text { jumlah larva udang } \\
\text { Ku } & : \text { kumulatif } \\
\text { TH } & : \text { total hidup } \\
\text { TM } & : \text { Total Mati } \\
\text { TKu } & : \text { Totak kumulatif } \\
\% \mathrm{~K} & : \text { persen Kematian }
\end{array}
$$

Keterangan :

1. Replikasi 1 = Perlakuan 1 uji toksistas ektrak temu hitam.
2. Replikasi 2 = Perlakuan ke 2 uji toksistas ektrak temu hitam.

3. Replikasi $3=$ Perlakuan ke 3 uji toksistas ektrak temu hitam.

Persen kematian $=\frac{\text { kumwlatif mati }}{\text { Total kwmulatif }}$

Tabel III. Hasil Pengamatan Kematian Larva Udang (Artemia salina Leach) Setelah Diberikan Ekstrak Rimpang Temu Hitam (Curcuma aeruginosa Robx.) Berdasarkan Metode Probit

\begin{tabular}{ccccccc}
\hline $\begin{array}{c}\text { Konsen } \\
\text { trasi } \\
(\mathbf{p p m})\end{array}$ & $\begin{array}{c}\text { \% } \\
\text { Kema } \\
\text { tian }\end{array}$ & $\begin{array}{c}\text { Log } \\
\text { Konsen } \\
\text { trasi } \\
(\mathbf{x})\end{array}$ & $\begin{array}{c}\text { Probit } \\
(\mathbf{y})\end{array}$ & $\mathbf{x}^{\mathbf{2}}$ & $\mathbf{y}^{\mathbf{2}}$ & $\mathbf{X y}$ \\
\hline $\mathbf{2 0}$ & 17,46 & 1,30 & 4,065 & 1,69 & 16,5242 & 5,2845 \\
\hline $\mathbf{4 0}$ & 45 & 1,60 & 4,87 & 2,56 & 23,7169 & 7,792 \\
\hline $\mathbf{6 0}$ & 70,31 & 1,78 & 5,535 & 3,1684 & 30,6362 & 9,8523 \\
\hline $\mathbf{8 0}$ & 90,78 & 1,90 & 6,31 & 3,61 & 39,8161 & 11,989 \\
\hline $\mathbf{1 0 0}$ & 98,97 & 2 & 7,19 & 4 & 51,6961 & 14,38 \\
\hline $\mathbf{\Sigma}$ & - & $\mathbf{8 , 5 8}$ & $\mathbf{2 7 , 9 7}$ & $\mathbf{1 5 , 0 2 8 4}$ & $\mathbf{1 6 2 . 3 8 9 5}$ & $\mathbf{4 9 , 2 9 7 8}$ \\
\hline
\end{tabular}

\section{B. Pembahasan}

Penelitian ini menggunakan tanaman temu hitam yang diperoleh dari kelurahan Lemo Kecamatan Mengkendek Kabupaten Tana Toraja Provinsi Sulawesi Selatan, Bagian tanaman yang digunakan sebagai sampel yakni rimpang. Rimpang ini sebelum dilakukan proses ekstraksi maka terlebih dahulu dikeringkan dengan cara diangin-anginkan untuk mengurangi kadar air dalam rimpang tersebut, setelah itu dilakukan proses ekstraksi dengan menggunakan metode maserasi. Maserasi merupakan proses penyarian senyawa kimia secara sederhana dengan cara merendam simplisia atau tumbuhan pada suhu kamar dengan menggunakan pelarut yang sesuai sehingga bahan menjadi lunak dan larut. Penyarian zat-zat berkhasiat dari simplisia, baik simplisia dengan zat berkhasiat yang tidak tahan pemanasan. Serbuk dari simplisia kering rimpang temu hitam ditimbang sebanyak $500 \mathrm{~g}$ kemudian diekstraksi dengan teknik maserasi selama 5 hari menggunakan pelarut etanol dan diperoleh ekstrak kental sebanyak $45 \mathrm{~g}$. Ekstrak kental yang didapatkan dilakukan pengujian bebas etanol untuk mengetahui secara kualitatif ada atau tidaknya etanol dari ekstrak tersebut yang akan digunakan dalam pengujian toksisitas menggunakan metode Brine Shrimp Lethality Test (BSLT).

Ekstrak rimpang temu hitam kemudian dibuat larutan ekstrak uji, ekstrak tersebut ditimbang sebanyak $100 \mathrm{mg}$ terlebih dahulu dilarutkan menggunakan DMSO 2\% 1-3 tetes dikarenakan ekstrak tidak larut, DMSO merupakan salah satu zat yang bersifat toksik, 
namun pada penelitian ini kadar DMSO yang digunakan tidak termasuk dalam kategori yang toksik karena DMSO yang digunakan $2 \%$ sedangkan efek toksik baru akan timbul ketika DMSO dimasukkan sebanyak 7\%. Kemudian ekstrak tersebut dibuat dalam berbagai konsentrasi, yaitu $20 \mathrm{ppm}, 40 \mathrm{ppm}, 60 \mathrm{pm}, 80$ ppm, dan 100 ppm, masing-masing konsentrasi tersebut dibuat dalam 3 replikasi. Setelah itu, dilakukan penetasan telur udang Artemia salina Leach menjadi larva proses penetasan ini dilakukan selama 2 × 24 jam yang disimpan dalam wadah botol plastik dengan dilengkapi aerator sebagai sumber oksigen dan lampu neon agar suhu tetap hangat. Larva yang menetas dan siap digunakan dalam pengujian BSLT, setiap 10 ekor dimasukkan kedalam vial yang berisi dengan larutan ekstak uji sesuai dengan konsentrasi masing-masing, berisikan $10 \mathrm{~mL}$ air laut buatan dan juga berisikan 1 tetes ragi yang berguna untuk sumber makanan larva. Selain itu dibuat pula kontrol negatif berupa air laut buatan dan larva udang tanpa penambahan ekstrak. Hal ini dilakukan untuk mengetahui pengaruh air laut buatan maupun faktor lain terhadap kematian hewan uji. Sehingga dapat dipastikan bahwa kematian larva hanyalah akibat dari penambahan ekstrak yang dilakukan. Pengamatan dilakukan setelah 1 x 24 jam dengan melihat jumlah larva yang mati dan hidup, setelah itu dilakukan perhitungan $\mathrm{LC}_{50}$ dari ekstrak tersebut dengan cara melakukan perhitungan $\%$ mortalitas yang kemudian menentukan persamaan linear dari ekstrak uji dengan cara mengregresikan pada grafik log konsentrasi, dan \% kematian. Untuk menentukan nilai probit maka terlebih dahulu diketahui nilai dari log konsentrasi dan \% mortalitas.

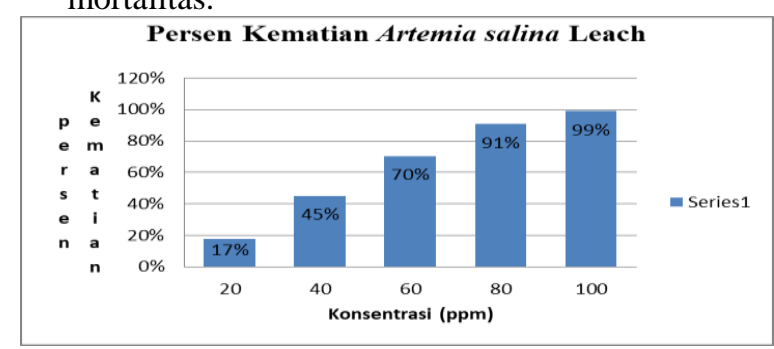

Gambar 1. Persen Kematian Hewan Uji Artemia salina Leach setelah di inkubasi.

Dari ekstrak etanol rimpang temu hitam yang diuji didapatkan hasil ekstrak menunjukkan nilai $\mathrm{LC}_{50} \quad 37,73115$ ppm. Berdasarkan persentase kematian larva udang pada penelitian tersebut menunjukkan bahwa jumlah kematian larva pada konsentrasi 20 ppm sebanyak $17,46 \%$ sedangkan konsentrasi 40 ppm sebanyak $45 \%$. Lalu pada konsentrasi 60 ppm total kematian larva yaitu $70,31 \%$, jika dibandingkan dengan total kematian larva pada konsentrasi 80 ppm yaitu $90,78 \%$ maka terlihat peningkatan. dan pada konsentrasi $100 \mathrm{ppm}$ yaitu $98,97 \%$. Sehingga dapat disimpulkan bahwa peningkatan konsentrasi yang semakin tinggi akan meningkatan kematian larva.

Total larva yang digunakan pada penelitian ini dengan 3 kali percobaan sebanyak 30 ekor. Sehingga total larva yang digunakan pada seluruh percobaan sebanyak 180 ekor. Total kematian diperoleh dengan menjumlah kematian larva pada setiap konsentrasi. Ratarata kematian diperoleh dari kematian dibagi total larva yang digunakan tiap konsentrasi. Persentase kematian didapat dengan mengalikan rata-rata kematian dengan 100 .

Senyawa yang menyebabkan efek toksik dari rimpang temu hitam pada larva udang yaitu terdapat kandungan seperti alkaloid, flavonoid, dan saponin, pada kadar tertentu memiliki potensi toksisitas akut serta dapat menyebabkan kematian larva Artemia salina Leach. Mekanisme kematian larva berhubungan dengan fungsi senyawa alkaloid, saponin dan flavonoid dalam rimpang temu hitam yang dapat menghambat daya makan larva (antifedant). Cara kerja senyawa-senyawa tersebut adalah dengan bertindak sebagai stomach poisoning atau racun perut. Oleh karena itu, bila senyawasenyawa ini masuk ke dalam tubuh larva, alat pencernaannya akan terganggu. Selain itu, senyawa ini menghambat reseptor perasa pada daerah mulut larva. Hal ini mengakibatkan larva gagal mendapatkan stimulus rasa sehingga tidak mampu mengenali makanannya sehingga larva mati kelaparan. ( Rita WS, Suirta IW, Sabikin A, 2008).

Hasil uji toksisitas ekstrak rimpang temu hitam yang ditunjukkan oleh grafik di atas dapat disimpulkan bahwa semakin tinggi konsentrasi suatu ekstrak maka akan semakin tinggi tingkat kematian larva. Hasil BSLT merupakan suatu metode penapisan untuk penyarian senyawa antikanker dari tanaman. Artinya adalah, bahwa semakin tinggi tingkat toksisitas metabolit sekunder tanaman secara BSLT, yang diwakili dengan nilai $\mathrm{LC}_{50}$ yang semakin kecil, maka semakin potensial tanaman tersebut untuk digunakan dalam pengobatan antikanker menurut mayer. Menurut Albuntana, dkk, (2011) dikatakan sangat aktif jika mendekati nilai standar keaktifan dari National Cancer Institute (NCI) Amerika yang menyatakan standar efektifitas komponen bioaktif untuk melawan sel kanker adalah $\leq 30 \mathrm{ppm}$. 


\section{PENUTUP}

\section{A. Kesimpulan}

Berdasarkan atas hasil penelitian dan pembahasan maka didapatkankan bahwa untuk pengujian toksisitas yaitu ekstrak etanol rimpang temu hitam didapatkan harga $\mathrm{LC}_{50}$ sebesar 37,73115 ppm, maka dapat disimpulkan ekstrak temu hitam tersebut memiliki potensi toksisitas masuk dalam kategori toksisitas kuat dengan LC $_{50}$ 30-100 ppm dan menunjukkan bahwa nilai tersebut masuk dalam katerori racun sedang serta memberikan efek toksik terhadap Artemia salin Leach pada konsentrasi 20 ppm sebesar 17,46\%, 40 ppm 45\%, 60 ppm 70,31\%, 80 ppm 90,78\% dan 100 ppm 98,97\%.

B. Saran

Sebaiknya peneliti selanjutnya melakukan fraksinasi terhadap ekstrak untuk uji toksisitas dari temu hitam (Curcuma aeruginosa Roxb.) sehingga diketahui potensi antikanker dari tumbuhan ini.

\section{DAFTAR PUSTAKA}

Alam, G, 2003. BSLT Sebagai Biossays dalam Isolasi Senyawa Bioaktif dari Bahan Alam. Majalah Farmasi dan Farmakologi. Vol.6.

Agoes, G. 2007. Teknologi Bahan Alam. Bandung : Penerbit ITB Press.

Dalimartha S. 1999. Atlas Tumbuhan Obat Indonesia Jilid I. Trubus Agriwidya : Jakarta

Depkes RI. 1986. Vademekum Bahan Obat Alam. Departemen Kesehatan Republik Indonesia : Jakarta

Depkes RI. 1995. Farmakope Indonesia Edisi IV. Departemen Kesehatan Republik Indonesia : Jakarta

Depkes RI. 2000. Acuan Sediaan Herbal. Departemen Kesehatan Republik Indonesia : Jakarta

Dewanti, F. 2018. Uji Toksisitas Ekstrak Klika Kersen (Mutinia calabura L). dengan Variasi Pelarut Menggunakan Metode Brine Shrimp Lethality Test (BSLT). Skripsi Tidak Diterbitkan. Makassar. Sekolah Tinggi Ilmu Farmasi.

Dumitrascu, M. 2011. Artemia salina, Balneo Research Jurnal. Vol 29 No 4;119-122.
Fitri H,. 2015. Aktivitas Esktrak Etanol Temu Hitam (Curcuma aeruginosa Roxb.) Sebagai Antiproliferasi Pada Sel Lestari Tumor, Skripsi Tidak Diterbitkan. Bogor. Fakultas Kedokteran Hewan, Institut Pertanian Bogor.

Frank, C. 1995. Toksikologi Dasar. Edisi Ke-2. Jakarta : Universitas Indonesia Press.

Hariana, A. 2006. Tumbuhan Obat dan Khasiatnya Seri Pertama, Jakarta; Penerbit Penebar Swadaya.

Harmita dan Radji M . 2008 . Buku Ajar Analisis Hayati. Penerbit Buku Kedokteran EGC : Jakarta

Ibrahim, S. dan Marham, S., 2013, Teknik Laboratorium Kimia Organik. Yogyakarta : Graha Ilmu.

Khodijah B. dan Enny Fachriyah, 2013, Daya Antibakteri Berbagai Konsentrasi Rimpang Temu Hitam (Curcuma aeruginosa Roxb.) Terhadap Bacillus subtitullis dan Staphylococus aureus Secara Invitro. Jurnal Biologi. Vol. 2 No. 4.

Kanwar, A. 2007. Brine Shrimp (artemia salina) Marine Animal for simple and Rapid Biological Assays. Journal of Chinese Clinical Medicine. Vol.2 (4); 236-240.

Koeman, J. H. 2011. Pengantar Umum Toksikologi. Gadjah Mada University Press: Yogyakarta 